(7)

\title{
Human Development, Political Stability and Economic Growth: The way forward
}

\section{${ }^{a}$ Areeba Khan, ${ }^{b}$ Sulaman Hafeez Siddiqui, ${ }^{c}$ Shahid Hussain Bukhari, ${ }^{d}$ Syed Muhammad Hashim Iqbal}

${ }^{a}$ Department of Management Sciences, The Islamia University of Bahawalpur, Pakistan

Email : areeba.khan@iub.edu.pk

${ }^{\mathrm{b}}$ Department of Management Sciences, The Islamia University of Bahawalpur, Pakistan

Email : sulman.siddiqui@iub.edu.pk

c Department of International Relations, Bahauddin Zakariya University, Multan, Pakistan

Email : shahidbukhari@bzu.edu.pk

d The Islamia University of Bahawalpur, Pakistan

Email : hashimiqbal221@gmail.com

\begin{tabular}{ll}
\hline ARTICLE DETAILS & ABSTRACT \\
\hline History: & Economic growth has been known to foster human development for long \\
Accepted 26 April 2020 & term economic stability. The evidence of bi-causality in the human \\
Available Online 15 June 2020 & development and economic growth nexus is however limited. This paper \\
& builds on the reverse causality between human development and \\
& economic growth in context of Pakistan, with the moderating impact of \\
Keywords: & political stability. The study applies OLS and VECM on the data collected \\
Economic Growth, Human & from World Bank Database from year 20o6 to 2018. Our findings exhibit \\
Development, Happiness, Income & empirical evidence related to endogenous growth models and a \\
Redistribution, Health & significant causal relationship between human development and \\
JEL Classification: & economic growth, moderated by political stability. The relationship is \\
O47, O15, D31 & further explained by trajectories of happiness, health and income \\
& redistribution. Our findings suggest efficient reallocation of resources \\
& towards human development to address post pandemic growth concerns.
\end{tabular}

DOI: $10.47067 /$ reads.v6i2.213

(C) 2020 The authors. Published by SPCRD Global Publishing. This is an open access article under the Creative Commons Attribution-

NonCommercial 4.0

Corresponding author's email address: areeba.khan@iub.edu.pk

\section{Introduction}

Pakistan is facing a huge economic crisis in form of upcoming post pandemic recession. As a developing country its primary concern is to develop assets that may propel it out of economic recession and foster growth in the country to deal with the havoc wrought by Covid-19 and resultant economic, political and social vulnerabilities.

Economic growth may be considered a direct trigger for human development for the nature and magnitude of investments in the social economy. The economic productivity contributes towards 


\section{Review of Economics and Development Studies, Vol. 6 (2) 2020, 351-361}

fulfillment of individual and institutional needs for sustaining general well-being. Empirical evidence confirms that high economic growth sustained for a longer period of time may result in higher per capita income and better living standard addressing basic needs to health and education (Sen, 200o; Butler \& Kern, 2016).

Where economic growth cannot be considered the sole contributor towards human development, its role is undeniable. In absence of economic growth, human capital cannot be expected to flourish and expound. There may however be other factors that can strengthen or weaken that relationship. Political stability, happiness and health are such factors which may create social capital of an economy (Easterlin, 2005). Political sponsorship of human development may play role of a catalyst in strengthening the growth and development nexus, as general well-being of masses is not only a public objective but also an imperative for sustainable political prowess.

The nature of causal antecedent relevant to economic growth has been addressed through empirical literature on economics; however, bi-causality or reverse causality of the situation has only been referred to in a perfunctory manner. This study seeks to analyze the reverse causality of the relationship between economic growth and human development theoretically and empirically.

\section{Brief Review of Literature}

Historically, Gross Domestic Product (GDP) has been used as an indicator of general well-being of a population (Sen, 1990). There may definitely be a positive correlation of productivity and wealth generation leading to personal comfort and development, however, distribution of income and the way it impacts general well being are the more conclusive factors. Where it cannot be denied that rich countries may have a better education and health system, it is also true that some states may prioritize growth than development (Solow, 1958). GDP falls short as a measure of wellness owing to its inability to reflect the cost of subjective well-being, freedom of thought and cost of living (Jolly, Emmerij \& Weiss, 2009).

Few alternatives of GDP as a measure of well being have been proposed over time, including Genuine Progress Indicator (GPI) based on expenditure patterns (Larsen, 2009), Human Development Index (HDI) focusing on human life longevity, literacy and productivity (Cummins et al., 2003) and the Millennium Ecosystem Assessment (MEA) focusing on human ecosystem (Carpenter et al., 2009). None of these measures captures all aspects of social and physical well-being. Easterlin (2003) argues that inadequacy of any singe measure may be attributed to hedonic adaptation of humans to different set of choices available in life. The social evaluation of peers compels them to accede to different decisions having a long-lasting impact of life, thereby refuting the established set of theories. Eckersley (1999) postulated a multivariate model of well-being which may account for social and personal life satisfactory as discount factors.

\section{Human Development and Growth Linkage}

The theoretical foundations human development could be traced back to Sen's capability strategy theory in 1985 where it was postulated that a person's well being and development depends upon number of vectors performing together in harmony. All developments in human capital formation theories can be attributed to the vectors of income health, happiness, education but is not limited to the same (Sen, 2000). Human Development Report was the first attempt at classifying not individuals but nations with respect to well-being (UNDP, 1990). Literacy rate, average life expectancy and GDP were few of the vectors used among others, in the UNDP report. With the passage of time, there has been an increase in the vectors, however, crucial elements for economic development like political stability and 
income inequality have not been added to the criteria, which may have compromised the accuracy of the index (Schultz, 2000).

The nature of relationship of growth with human development has been discussed in the perspective of growth as a determinant of human development, identifying vicious circle in low growth and low human development as well limitations in high growth and staggered human development (McAllister, 2005). The staggered development in high growth economies indicates the fact that growth and human development relationship may not be direct and there could be other factors mediating the nexus.

\subsection{Happiness, Well-Being and Health}

Comprehensive review of literature on happiness shows its origin as a way of life from Buddhist doctrine. Life satisfaction, well-being and happiness are used interchangeably as a manifestation of inner peace and happiness in the Buddhist religion (McAllister, 2005). Self-evaluated happiness has been the major assessment tool in literature of well-being (Diener et al., 2009). The GNH framework however uses health as the major evaluator of well-being. Diener et al. (1985) developed a multiscale assessment of happiness using overall satisfaction from life, based on factor analysis driven from cultural aspects.

\subsection{Income redistribution and growth}

Income redistribution and growth relationship is not as straight forward as the linkage between income inequality and economic development. Sharp in 2004 studied the nexus between income redistribution and production efficiency and concluded that income inequality results in decreased productivity as growth gets discounted. Some popular means of calculating income inequality through redistribution include Atkinson Index, Squared Coefficient of Variation (SCV), and Mean-Log Deviation (MLD) (Cardoso, 1993). The link between income redistribution, growth and happiness may also be significantly affected by expenditure on health (Bhargava et al., 2001; Mayer, 2001).

\begin{tabular}{|c|c|c|c|}
\hline Variable & Proxy & Description & Source \\
\hline $\begin{array}{l}\text { Economic } \\
\text { Growth }\end{array}$ & E.G & $\begin{array}{l}\text { Growth may have a strongly positive impact on human } \\
\text { development as per literature. It is mentioned as a viable indicator } \\
\text { in competency variables (Solow, 1958). }\end{array}$ & $\begin{array}{l}\text { Word } \\
\text { Bank }\end{array}$ \\
\hline $\begin{array}{l}\text { Human } \\
\text { Development }\end{array}$ & H.D & $\begin{array}{l}\text { The impact of growth on human development has been discussed, } \\
\text { but the bi-causality of the relationship is yet to be determined. } \\
\text { Human development is the primary and perhaps terminal objective } \\
\text { of economic growth but can it trigger growth in return must also } \\
\text { be explored (Alkire, 2010). }\end{array}$ & $\begin{array}{l}\text { Word } \\
\text { Bank }\end{array}$ \\
\hline $\begin{array}{l}\text { Income } \\
\text { Redistribution }\end{array}$ & I.R & $\begin{array}{l}\text { Income inequality may hinder growth prospects since it decreases } \\
\text { productivity by compromising incentives to productivity (Anand, } \\
\text { Sudhir \& Sen, 2000). }\end{array}$ & $\begin{array}{l}\text { Word } \\
\text { Bank }\end{array}$ \\
\hline $\begin{array}{l}\text { Happiness } \\
\text { Index }\end{array}$ & H.I & $\begin{array}{l}\text { Happiness index considers general well being and happiness of } \\
\text { individuals as well as nations. It is a robust indicator of social } \\
\text { productivity (Adler \& Seligman, 2016). }\end{array}$ & $\begin{array}{l}\text { Word } \\
\text { Bank }\end{array}$ \\
\hline
\end{tabular}


Review of Economics and Development Studies, Vol. 6 (2) 2020, 351-361

\begin{tabular}{|l|l|l|l|}
\hline Health & HL & $\begin{array}{l}\text { Health as a function of income and social privilege may impact the } \\
\text { gross national well being of nations in a strategic way. It is vital } \\
\text { towards determining happiness, average age and mortality (Butler } \\
\text { \& Kern, 2016). }\end{array}$ & $\begin{array}{l}\text { Wank } \\
\text { Bank }\end{array}$ \\
\hline $\begin{array}{l}\text { Political } \\
\text { Stability }\end{array}$ & P.St & $\begin{array}{l}\text { Political stability may prove vital in mediating the effect of human } \\
\text { development on economic growth through changing public } \\
\text { expenditure patterns and fiscal policy (Paul, 1979 Sen, 2ooo). }\end{array}$ & Bank \\
\hline
\end{tabular}

\section{Method}

Data were collected from the World Bank database over the period of 13 years from 2006-2018. Pakistan has always experienced negative ratings on political stability and low rankings on happiness index (rank 66) as compared to other emerging economies (see table ). The data collected for happiness index reflects on social support and perceived corruption. The differentiating factor between high rank and low rank countries seem to be the social harmony between individuals and institutions (World Happiness Report, 2020). Pakistan's rank in 2018 seems to improve owing to regime change and perception of lower corruption, scoring an average 5.38 and a maximum of 5.69 points in the year 2020.

In the same time span Pakistan's health spending per capita increased to $\$ 44.59$ from an average of \$21. Health spending as percentage of GDP however saw a steep decline from year 2007-2012 and then regained to maintain average of $2.9 \%$, whereas comparative average for the world economies is $6.55 \%$. The stark difference in health expenditure may account for decline in general well-being and happiness.

Figure 1: Descriptives
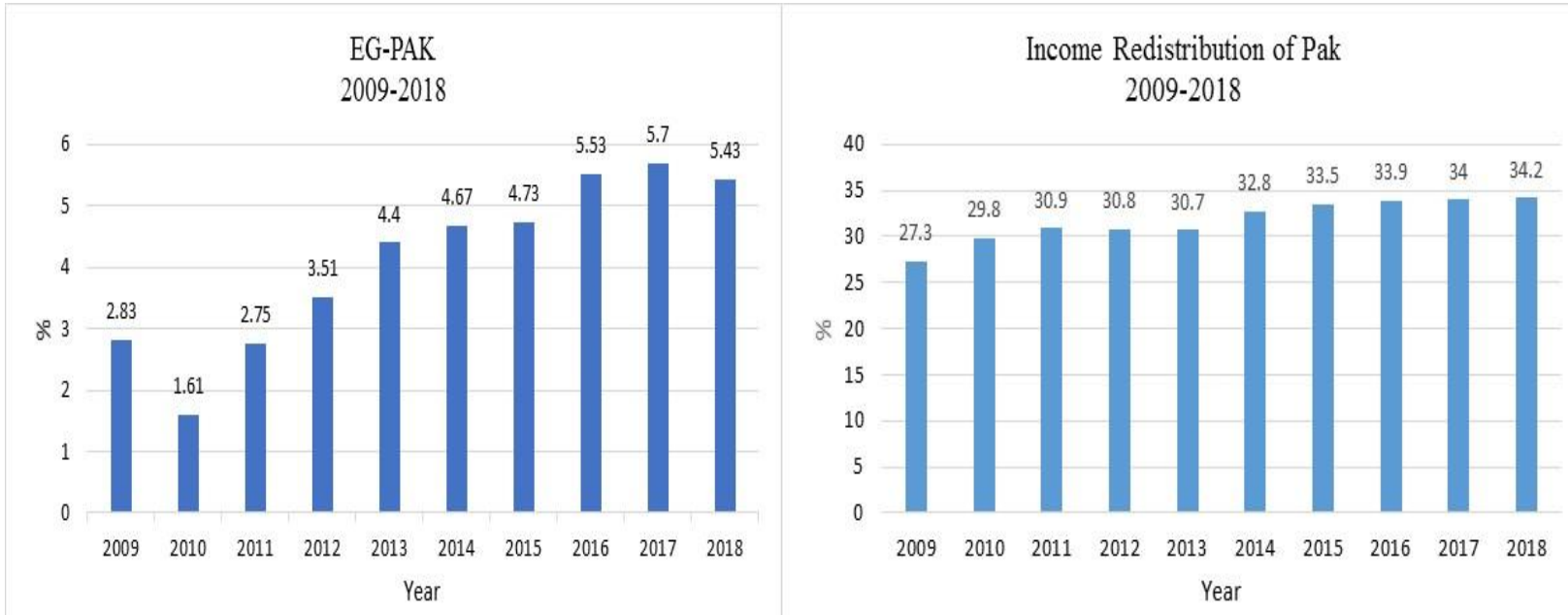


\section{Review of Economics and Development Studies, Vol. 6 (2) 2020, 351-361}
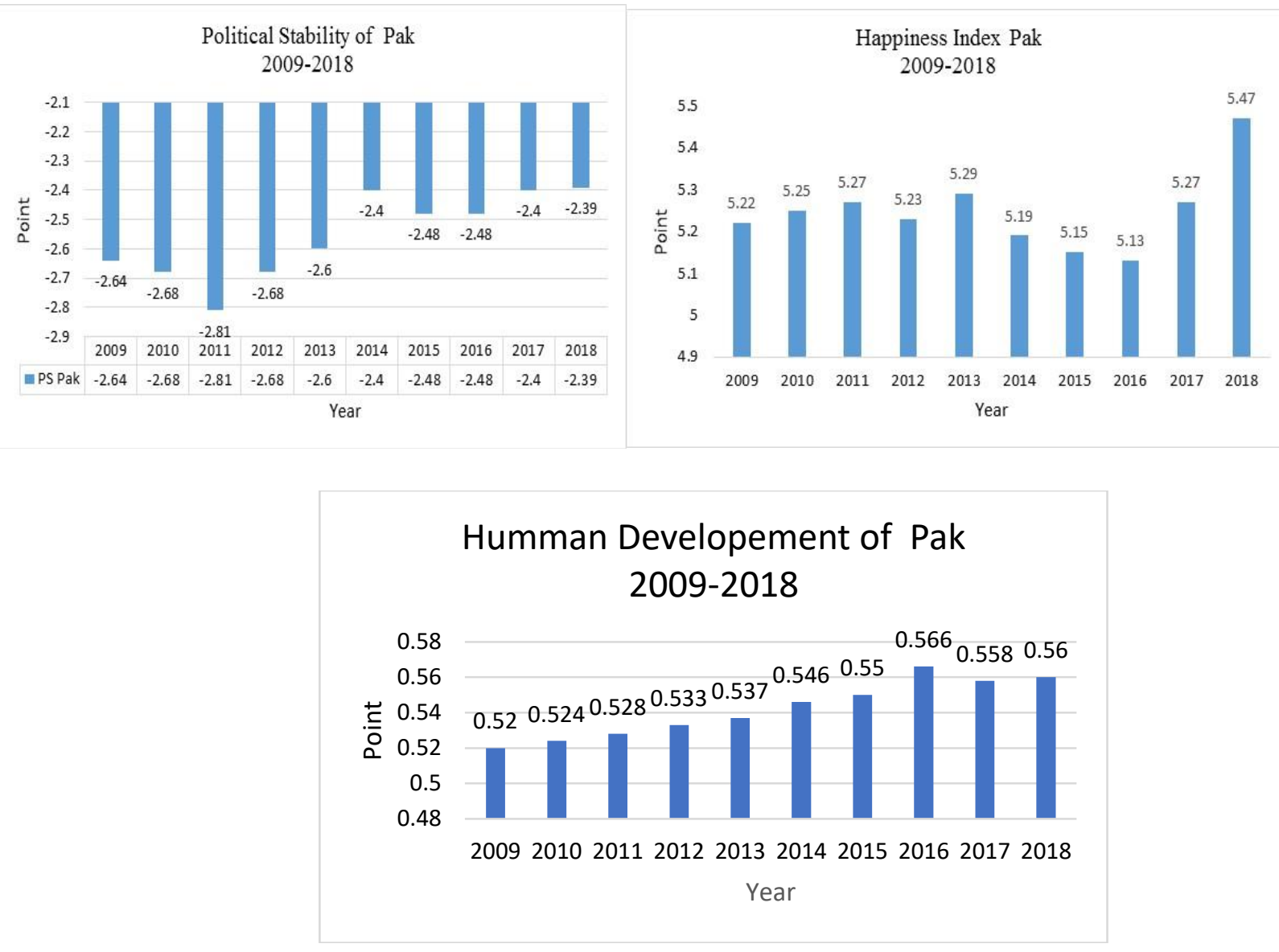

Source: World Bank Database- UNDP, 2020

For income inequality and redistribution, the value of Gini income inequality index is 33.5, hovering around an average of 31 points. The top $10 \%$ income share of earners is $29.5 \%$. The world average for income of top 10 earners based on $n 74$ countries is $28 \%$. The ratio shows minimum or no improvement from an average of $27 \%$ in most years.

Pakistan has seen a drastic decline in GDP growth rate from an 5.83\% to a staggering $3 \%$ in the year 2020. The long-term growth forecasts for the country look dismal in context of Covid-19 pandemic and increased pressures for debt servicing.

Political stability has always seen negative values for Pakistan. Pakistan score 94.2 at a 120 points index for a fragile state. The latest score at political stability index of Pakistan is $\mathbf{- 2 . 2 7}$, which exhibits a weak political scenario.

Human development like other indicators is at a decline from year 2018 onwards. Basic reason for this decline is attributed to decrease in expenditure on health and education. The HDI value for 2018 is 0.560 for Pakistan which indicates state of medium development.

Economic Growth is taken as the dependent variable, whereas Human Development, Income Redistribution, Happiness Index and Health as Independent Variables representing Gross National wellbeing. Political Stability is taken as a Moderator variable. Descriptive statistics were taken, correlation and OLS estimated and Vector Error Correction Model was run on the data for cointegration. 
Review of Economics and Development Studies, Vol. 6 (2) 2020, 351-361

\section{Findings and discussion}

Descriptive statistics were run on the data and the results are mentioned in table 1.

TABLE 1: DESCRIPTIVES

\begin{tabular}{|l|c|c|c|c|c|c|}
\hline Descriptives & EG-PAK & HD-PAK & HI-PAK & HL-PAK & IR-PAK & PS-PAK \\
\hline Mean & 4.11 & 0.54 & 5.24 & 2.62 & 31.79 & -2.55 \\
\hline Median & 4.53 & 0.54 & 5.24 & 2.65 & 31.85 & -2.54 \\
\hline Maximum & 5.70 & 0.56 & 5.47 & 2.80 & 34.20 & -2.39 \\
\hline Minimum & 1.61 & 0.52 & 5.13 & 2.34 & 27.30 & -2.81 \\
\hline $\begin{array}{l}\text { Std. } \\
\text { Deviation }\end{array}$ & 1.38 & 0.01 & 0.09 & 0.16 & 2.26 & 0.14 \\
\hline Skewness & -0.49 & 0.07 & 1.18 & -0.79 & -0.61 & -0.29 \\
\hline Kurtosis & 2.01 & 1.61 & 4.31 & 2.38 & 2.40 & 1.81 \\
\hline Jarque-Bera & 0.81 & 0.80 & 3.05 & 1.21 & 0.78 & 0.72 \\
\hline Probability & 0.66 & 0.66 & 0.21 & 0.54 & 0.67 & 0.69 \\
\hline Sum & 41.16 & 5.42 & 52.47 & 26.26 & 317.90 & -25.56 \\
\hline Sum Sq. Dev. & 17.16 & 0.00 & 0.08 & 0.23 & 46.16 & 0.19 \\
\hline
\end{tabular}

OLS regression (table 2) was run on the data with Economic growth as dependent variable and Human development, Income redistribution, Happiness index and health as predictors. The results show Human development significant at the level of 10\%, with overall predictive power of the model as exhibited by Adjusted $\mathrm{R}^{2}$ at $87.80 \%$. The results show a strong causal relationship between Human development and economic growth.

TABLE 2: OLS RESULTS

\begin{tabular}{|l|l|l|l|}
\hline Variable & Coefficient & Std. Error & t-statistic \\
\hline C & -51.20 & 20.72 & $\begin{array}{l}-2.47 \\
(0.05)\end{array}$ \\
\hline HD-PAK & 109.29 & 49.52 & $\begin{array}{l}2.20 \\
(0.07)\end{array}$ \\
\hline HI-PAK & 0.68 & 2.33 & $\begin{array}{l}0.29 \\
(0.78)\end{array}$ \\
\hline HL-PAK & -0.31 & 2.07 & $\begin{array}{l}-0.15 \\
(0.88)\end{array}$ \\
\hline IR-PAK & -0.21 & 0.30 & $\begin{array}{l}-0.69 \\
(0.51)\end{array}$ \\
\hline R-Squared & 0.87 & Mean dependent Var & 4.11 \\
\hline Adjusted- R Squared & 0.78 & S.D. dependent var & 1.38 \\
\hline S.E of regression & 0.64 & Akaike info criterion & 2.27 \\
\hline Sum squared Resid & 2.09 & Schwarz criterion & 2.42 \\
\hline Log Likelihood & -6.36 & Hannan-Quinn criterion & 2.10 \\
\hline F-Statistic & 9.00 & Durbin-Watson stat & 2.08 \\
\hline Prob (F-Statistic) & 0.01 & & \\
\hline
\end{tabular}


Review of Economics and Development Studies, Vol. 6 (2) 2020, 351-361

OLS regression was run again with the moderator Political stability to gauge the effect of moderating variable on the relationship between Human development and economic growth. The results not only show a higher predictive capacity of the model with Adjusted $\mathrm{R}^{2}$ of $93.48 \%$ but also turn Human development significant at the level of 5\%. The Durbin Watson stat for first order serial correlation is 3.31, which is a good sign since it is above 2 .

TABLE 3: VAR

\begin{tabular}{|l|l|l|l|}
\hline Variable & Coefficient & Std. Error & t-statistic \\
\hline C & -16.54 & 25.14 & $\begin{array}{l}-2.47 \\
(0.54)\end{array}$ \\
\hline HD-PAK & 107.49 & 40.49 & $\begin{array}{l}2.20 \\
(0.05)\end{array}$ \\
\hline HI-PAK & 0.75 & 1.91 & $\begin{array}{l}0.29 \\
(0.71)\end{array}$ \\
\hline HL-PAK & -4.77 & 2.93 & $\begin{array}{l}-0.15 \\
(0.17)\end{array}$ \\
\hline IR-PAK & -0.34 & 0.25 & $\begin{array}{l}-0.69 \\
(0.24)\end{array}$ \\
\hline PS-PAK & 7.10 & 3.75 & $\begin{array}{l}1.86 \\
(0.13)\end{array}$ \\
\hline R-Squared & 0.93 & Mean dependent Var & 4.11 \\
\hline $\begin{array}{l}\text { Adjusted- R } \\
\text { Squared }\end{array}$ & 0.85 & S.D. dependent var & 1.38 \\
\hline S.E of regression & 0.52 & Akaike info criterion & 1.84 \\
\hline $\begin{array}{l}\text { Sum squared } \\
\text { Resid }\end{array}$ & 1.11 & Schwarz criterion & 2.02 \\
\hline Log Likelihood & -3.23 & Hannan-Quinn criterion & 1.64 \\
\hline F-Statistic & 11.47 & Durbin-Watson stat & 3.31 \\
\hline $\begin{array}{l}\text { Prob (F- } \\
\text { Statistic) }\end{array}$ & 0.01 & & \\
\hline
\end{tabular}

TABLE 4: CORRELATION

\begin{tabular}{|c|c|c|c|c|c|c|}
\hline \multirow{2}{*}{$\begin{array}{l}\text { Correlation } \\
\text { t-statistic } \\
\text { Probability }\end{array}$} & \multirow[b]{2}{*}{$E G-P A K$} & \multirow[b]{2}{*}{$H D-P A K$} & \multirow[b]{2}{*}{ HI-PAK } & \multirow[b]{2}{*}{$H L-P A K$} & \multirow[b]{2}{*}{$I R-P A K$} & \multirow[b]{2}{*}{$\begin{array}{l}\text { PS- } \\
P A K\end{array}$} \\
\hline & & & & & & \\
\hline EG-PAK & 1 & & & & & \\
\hline \multirow[t]{3}{*}{ HD-PAK } & 0.93 & 1 & & & & \\
\hline & 7.15 & --- & & & & \\
\hline & 0.00 & --- & & & & \\
\hline \multirow[t]{3}{*}{ HI-PAK } & 0.07 & 0.05 & 1 & & & \\
\hline & 0.22 & 0.15 & --- & & & \\
\hline & 0.83 & 0.88 & --- & & & \\
\hline HL-PAK & 0.68 & 0.71 & 0.09 & 1 & & \\
\hline
\end{tabular}


Review of Economics and Development Studies, Vol. 6 (2) 2020, 351-361

\begin{tabular}{|l|l|l|l|l|l|l|}
\hline & 2.64 & 2.89 & 0.28 & --- & & \\
\hline & 0.02 & 0.01 & 0.78 & --- & & \\
\hline IR-PAK & 0.83 & 0.93 & 0.09 & 0.57 & 1 & \\
\hline & 4.30 & 7.62 & 0.27 & 1.99 & --- & \\
\hline & 0.00 & 0.00 & 0.79 & 0.08 & --- & \\
\hline PS-PAK & 0.84 & 0.82 & 0.09 & 0.90 & 0.74 & 1 \\
\hline & 4.46 & 4.13 & 0.26 & 6.12 & 3.14 & --- \\
\hline & 0.00 & 0.00 & 0.79 & 0.00 & 0.01 & --- \\
\hline
\end{tabular}

HI_PAK (0.07) has a weak correlation with EG_PAK but HD_PAK (0.68) has a strong correlation with EG_PAK. Similarly, IR_PAK (0.83) has a strong correlation with EG_PAK. PS_PAK (o.84) has a strong correlation with EG_PAK. The presence of these afore mentioned correlations exhibit a sturdy covariance among variables, as mentioned in table 4 .

Vector Error Correction analysis is carried out on the data, and the results are explained in able. This output includes the analysis of Pakistan in which the EG_PAK as a dependent variable and the independent variables are (HL_PAK, IR_PAK, HD_PAK, HI_PAK) and PS_PAK as Moderator. The vector error correction equation is as:

VECM: $\Delta Y=\beta_{o}+\sum_{i=1}^{n} \beta_{i} \Delta Y_{t-i}+\sum_{i=0}^{n} \delta_{i} \Delta X_{t-i}+\vartheta Z_{t-1}+\mu_{i}$

From results the cointegrating equation coefficient is -1.5319 for the error correction term lag zero period and coefficient values of $\mathrm{x}$ for this lag are PS_PAK $=4.718$, IR_PAK $=0.282625$, HI_PAK $=1.609658$, HD_PAK=73.23038 and the constant $\mathrm{c}$ is -45.1584 .

The cointegrating equation for the long run model is as follows:

$$
Z_{t-1}=E C T_{t-1}=Y_{t-1}-\beta_{0}-\beta_{1} X_{t-1}
$$

\section{TABLE 5; VECM}

\begin{tabular}{|c|c|c|}
\hline \multicolumn{3}{|c|}{$\begin{array}{l}\text { Vector Error Correction } \\
\text { Standard Error () t-statistic [] }\end{array}$} \\
\hline EG-PAK $(-1)$ & 1 & \\
\hline \multirow[t]{3}{*}{ HL-PAK(-1) } & 1.43 & \\
\hline & -0.81 & \\
\hline & {$[1.75]$} & \\
\hline \multirow[t]{2}{*}{$\mathrm{C}$} & -7.70 & \\
\hline & D(EG-PAK) & D(HL-PAK) \\
\hline \multirow[t]{3}{*}{ Coint Eq.1 } & -1.53 & -0.05 \\
\hline & -0.59 & -0.06 \\
\hline & {$[-2.56]$} & {$[-0.84]$} \\
\hline \multirow[t]{3}{*}{$\mathrm{C}$} & -45.15 & 1.80 \\
\hline & -23.80 & -2.73 \\
\hline & [-1.89] & {$[0.66]$} \\
\hline \multirow[t]{2}{*}{ PS-PAK } & 4.71 & 1.60 \\
\hline & -4.49 & -0.51 \\
\hline
\end{tabular}


Review of Economics and Development Studies, Vol. 6 (2) 2020, 351-361

\begin{tabular}{|c|c|c|}
\hline & {$[1.05]$} & [3.10] \\
\hline \multirow[t]{3}{*}{ IR-PAK } & 0.28 & -0.19 \\
\hline & -0.41 & -0.04 \\
\hline & [0.68] & {$[-4.15]$} \\
\hline \multirow[t]{3}{*}{ HI-PAK } & 1.60 & 0.01 \\
\hline & -2.20 & -0.25 \\
\hline & [0.72] & [0.07] \\
\hline \multirow[t]{3}{*}{ HD-PAK } & 73.23 & 15.72 \\
\hline & -45.90 & -5.27 \\
\hline & [1.59] & [2.98] \\
\hline R Squared & 0.79 & 0.91 \\
\hline Adjusted R squared & 0.45 & 0.78 \\
\hline Sum Sq.resids & 0.86 & 0.01 \\
\hline S.E. Equation & 0.53 & 0.06 \\
\hline F-Statistic & 2.32 & 6.86 \\
\hline Log Likelihood & -2.24 & 17.23 \\
\hline Akaike AIC & 1.83 & -2.49 \\
\hline Schwarz SC & 1.96 & -2.36 \\
\hline Mean dependent & 0.28 & 0.02 \\
\hline SD dependent & 0.72 & 0.13 \\
\hline $\begin{array}{l}\text { Determinant resid covariance (dof } \\
\text { adj.) }\end{array}$ & \multirow{5}{*}{\multicolumn{2}{|c|}{$\begin{array}{c}0.00 \\
2.43 \text { E05 } \\
22.26 \\
-1.83 \\
-1.53\end{array}$}} \\
\hline Determinant resid covariance & & \\
\hline Log Likelihood & & \\
\hline Akaike AIC & & \\
\hline Schwarz SC & & \\
\hline
\end{tabular}

The results in table 6 show value of EG_PAK $(-1)=1.00$, HL_PAK $(-1)=1.43$ for the lag period zero and constant $\left(\beta_{0}\right)$ for the cointegrating equation is -7.70131 . The R-squared for this lag period is 0.79 and Adj. R-squared is 0.45 . This variance is obtaining by testing different combination of endogenous and exogenous variables, F-statistic for this analysis is 2.32 .

\section{Conclusion}

This study tests the hypothesis of reverse causality between Human Development and Economic growth, with the moderating impact of Political stability. The results show a high degree of causal relationship between human development and economic growth and a significant impact of political stability as a moderator. The effects of health, income redistribution and happiness index were also checked on economic growth and the former were found to be insignificant.

The empirical results of the study suggest that the level of human development would affect economic progress of a country over the long term. The results are significant for Pakistan as an emerging economy relying heavily on the services sector. Efforts to formulate and develop human capital may result in greater economic progress provided the country experiences political stability over time.

The policy implications drawn from the study could be intricate with respect to execution in times of staggering growth. Fiscal allocation of resources to the prioritized sectors may make 


\section{Review of Economics and Development Studies, Vol. 6 (2) 2020, 351-361}

substantial difference in human and physical capital formation. The government needs to formulate policies for efficient allocation to health and education, incentivize private sector for investments in human capital, and strengthen social sector investments to deal with human and political vulnerabilities. Economic stability and development may be consequential to social stability and human development in post pandemic regime.

\section{References}

Adler, A., \& Seligman, M. E. (2016). Using wellbeing for public policy: Theory, measurement, and recommendations. International journal of wellbeing, 6(1).

Alkire, S. (2010). Human Development: Definitions, Critiques, and Related Concepts. OPHI Working Paper No. 36. Oxford Poverty \& Human Development Initiative (OPHI). Available Online: http://www.ophi.org.uk/wp-content/uploads/OPHI_WP36.pdf

Anand, Sudhir and Amartya Sen (2000). The Income Component of the Human Development Index, Journal of Human Development, Vol. 1, No. 1, 2000

Anand, Sudhir and Amartya Sen (2000). The Income Component of the Human

Anand, Sudhir and Martin Ravallion (1993). Human Development in Poor Countries: On the Role of Private Incomes and Public Services, The Journal of Economic Perspectives, Vol. 7, No. 1, 133-150

Birdsall, N., Ross, D., \& Sabot, R. (1995). Inequality and growth reconsidered: lessons from East Asia. World Bank Economic Review, 9Colman R. Measuring progress towards GNH: From GNH Indicators to GNH National

Butler, J., \& Kern, M. L. (2016). The PERMA-Profiler: A brief multidimensional measure of flourishing. International Journal of Wellbeing, 6(3).

Carpenter, S. R., Mooney, H. A., Agard, J., Capistrano, D., DeFries, R. S., Diaz, S., et al. (20o9). Science for managing ecosystem services: beyond the millennium ecosystem assessment. Proc. Natl. Acad. Sci. U.S.A. 106, 1305-1312. doi: 10.1073/pnas.0808772106

Cummings, E. M., Goeke-Morey, M., \& Papp, L. (2003). Children's responses to everyday marital conflict tactics in the home. Child Development, 74, 1918-1929.

Development Index, Journal of Human Development, Vol. 1, No. 1, 2000

Diener E, Emmons RA, Larsen RJ, Griffin S. The Satisfaction with Life Scale. J Pers Assess 1985;49:71-5.

Diener, E. (2009). Subjective well-being. In The science of well-being (pp. 11-58). Springer, Dordrecht.

Diener, E., Scollon, C. N., \& Lucas, R. E. (2009). The evolving concept of subjective well-being: The multifaceted nature of happiness. In Assessing well-being (pp. 67-100). Springer, Dordrecht.

Easterlin, R. A.(2005a). Diminishing Marginal Utility of Income? Caveat Emptor, Social Indicators Research, 70(3), 243-55.

Eckersley, R. (1999a, 'Quality of Life in Australia', The Australia Institute, discussion paper, Canberra, Australia.

Institute of Wellbeing (2009). www.ciw.ca.

Jolly, R., Emmerij, L., \& Weiss, T.G. (2009). UN Intellectual History Project, Briefing Note Number, pages 1-6. Available Online: http://www.unhistory.org/briefing/8HumDev.pdf

Larsen, R. (2009). The contributions of positive and negative affect to emotional wellbeing. Psihologijske teme, 18(2), 247-266

Larsen, R. J., \& Eid, M. (2008). Ed Diener and the science of subjective well-being. The science of subjective well-being, 1-13.

McAllister, M., 2005. Transformative teaching in nursing education: preparing for the possible. Collegian 12 (1), 13-18.

Nefs, D. (2009). HDI Project Report, Summer 2009. Available Online: http://www.india.jbs.cam.ac.uk/engagement/tataises/downloads/report_nefsd.pdf

Population Reference Bureau (2004). Human Development Indicators, 127-138. Available 
Online: http://www.prb.org/source/hdr04_backmatter_1.pdf

Schultz, P. W. (2000). Empathizing with nature: The effects of perspective taking on concern for environmental issues. Journal of Social Issues, 56, 391-406.

Sen, A. (1999). Development as Freedom. Oxford: Oxford University Press.

Sen, Amartya (1985). Well-Being, Agency and Freedom: The Dewey Lectures 1984, The Journal of Philosophy, Vol. 82, No. 4, 169-221

Sen, Amartya (1985). Well-Being, Agency and Freedom: The Dewey Lectures 1984, The Journal of Philosophy, Vol. 82, No. 4, 169-221

Sharpe, A. and Smith, J. (2005) Measuring the Impact of Research on Well-being: a survey of indicators of wellbeing. Ottawa: CSLS.

Solow, R. M. (1958). A Contribution to the Theory of Economic Growth. Quarterly Journal of Economics, 65-94.

UNDP. (2020). Key to HDI countries and ranks. United Nations Development Programme. 